\title{
Yield and quality of tomato grown in a hydroponic system, with different planting densities and number of bunches per plant ${ }^{1}$
}

\author{
Flávio Barcellos Cardoso 2 , Herminia Emilia Prieto Martinez², \\ Derly José Henriques da Silva², Carla do Carmo Milagres², José Geraldo Barbosa²
}

\section{ABSTRACT}

Obtaining a high yield of good quality fruits is one of the main challenges of the tomato crop. The enhancement in plant density promotes a reduction in the fruit fresh mass and an increase the yield per area. On the other hand, commercialization parameters take into account number and fresh mass of fruits. This study aimed at evaluating the yield and fruit quality of indeterminate growth hybrid tomato (Rebeca), cultivated in a hydroponic system, with different planting densities and number of bunches per plant. The experiment was conducted under greenhouse conditions, in a sub-irrigation system containing expanded clay as substrate. A split-plot randomized block design, with three replications, was used. In the plots, four planting densities (11.1 plants $\mathrm{m}^{-2}$, 8.3 plants $\mathrm{m}^{-2}, 6.6$ plants $\mathrm{m}^{-2}$ and 5.5 plants $\mathrm{m}^{-2}$ ) were allocated and, in the subplots, the number of bunches per plant (one or two). The total yield was influenced by the interaction planting density x number of bunches per plant. The treatment that allowed the highest yield was 11.1 plants $\mathrm{m}^{-2}$ with two bunches, with $22.61 \mathrm{~kg} \mathrm{~m}^{-2}$ or $226.1 \mathrm{t} \mathrm{ha}^{-1}$, in a crop cycle of 134 days. The observed variations for the nutrient contents of leaves and fruits of tomato plants with one or two bunches, at densities of 5.5-11.1 plants $\mathrm{m}^{-2}$, do not compromise the fruit quality nor influence the production of tradable fruits, using the hydroponic system.

KEYWORDS: Solanum lycopersicum L.; nutritive solution; expanded clay.

\section{INTRODUCTION}

Tomato (Solanum lycopersicum L.) is among the most cultivated vegetables in Brazil. Due to its great acceptance in the market and compensating prices, tomato has been one of the most profitable vegetables for producers, being one of the most consumed and popular fruits of the world (Fernandes et al. 2002, Nasir et al. 2015). In addition to play

\section{RESUMO}

Produtividade e qualidade de tomate cultivado em sistema hidropônico, com diferentes densidades de plantio e número de cachos por planta

A obtenção de frutos de boa qualidade e com alta produtividade é um dos principais desafios da cultura do tomateiro. Com o adensamento de cultivo, há redução na massa fresca de frutos e aumento na produtividade por área; porém, a comercialização considera o número e a massa fresca de frutos. Objetivou-se avaliar a produtividade e a qualidade de frutos de tomateiro híbrido de crescimento indeterminado (Rebeca), cultivado em sistema hidropônico, com diferentes densidades de plantio e número de cachos por planta. O experimento foi conduzido em casa-devegetação, em sistema de subirrigação contendo argila expandida como substrato. O delineamento foi em blocos ao acaso, com parcelas subdivididas e três repetições. Nas parcelas, foram alocadas quatro densidades de plantio (11,1 plantas $\mathrm{m}^{-2} ; 8,3$ plantas $\mathrm{m}^{-2}$; 6,6 plantas $\mathrm{m}^{-2}$; e 5,5 plantas $\mathrm{m}^{-2}$ ) e, nas subparcelas, o número de cachos por planta (um ou dois). A produtividade total foi influenciada pela interação densidade de plantio x número de cachos por planta. O tratamento que possibilitou maior produção foi o de 11,1 plantas $\mathrm{m}^{-2}$ com dois cachos, com 22,61 $\mathrm{kg} \mathrm{m}^{-2}$ ou 226,1 tha-1, em um ciclo de cultivo de 134 dias. As variações observadas para os teores de nutrientes minerais nas folhas e frutos do tomateiro com um ou dois cachos, em densidades de 5,5-11,1 plantas $\mathrm{m}^{-2}$, não comprometem a qualidade dos frutos e nem influenciam na produção de frutos comercializáveis, no cultivo hidropônico.

PALAVRAS-CHAVE: Solanum lycopersicum L.; solução nutritiva; argila expandida.

an important role in the human diet, offering a diversified blend of nutrients (Ilahy et al. 2016), tomato is rich in protein and carbohydrates (Perveen et al. 2015). However, the main highlight given to tomato composition is the high levels of antioxidant compounds, such as phenolic compounds, vitamin C and carotenoids (Vinha et al. 2014).

Tomato cultivation is considered a high-risk activity, mainly due to the great susceptibility to

1. Received: Apr. 22, 2018. Accepted: Jul. 19, 2018. Published: Oct. 01, 2018. DOI: 10.1590/1983-40632018v4852611.

2. Universidade Federal de Viçosa, Departamento de Fitotecnia, Viçosa, MG, Brasil.E-mail/ORCID: flaviobarcellos@gmail.com/ 0000-0002-2029-4849, herminia.martinez@ufv.br/0000-0002-2184-374X, derly.silva@ufv.br/0000-0003-3963-1515, carlacmilagres@yahoo.com.br/0000-0002-9273-2609,jose.barbosa@ufv.br/0000-0001-7421-4392. 
the attack of diseases and pests, oscillation in the market prices and great requirement of inputs and services (Fernandes et al. 2007). The high costs for implementing and maintaining the crop and the demand of the market for better quality products stimulate the search for new cultivation and management alternatives.

Tomato production may be directly affected by planting density. Crops established in dense stands achieve better yields than the spaced ones (Santos et al. 2013, Hachmann et al. 2014). On the other hand, very dense stands may result in a decrease in the average fruit mass (Seleguini et al. 2002). Andriolo \& Falcão (2000) observed that plant density can be increased to improve the effect of leaf suppression without modifying the optimal leaf area index. However, the number of stems per plant and the use of apical pruning for a defined number of bunches also interfere with planting density and the source/ sink relationship, and can be alternative practices in its production (Silva et al. 2001).

According to Pereira et al. (1999), apical pruning also has the effect of favouring the increase of the size of already formed fruits, particularly those located in the upper third of the plant. However, several studies have shown varied effects of this technique on yield and fruit quality (Streck et al. 1998, Silva et al. 2001).

To minimize the existing difficulties, it is possible to cultivate tomato under more favourable conditions inside protected environments. The correct use of such technique allows reaching higher yields than in the field (Purquerio \& Tivelli 2006). The low yield, prolonged cultivation time and need for more crops per year to meet the market demands have attracted the producer interest in the hydroponic production system (Andriolo et al. 1999).

Hydroponic crops make it possible to obtain good quality products, when compared to conventional systems. The advantages in this system include the high crop quality and yield, lower expenses with fertilizers and a more efficient use of water, besides a reduction in the environmental pollution and a greater control and efficiency in the productive process (Logendra et al. 2001).

The hydroponic cultivation of tomato with a single bunch allows using high planting densities, since the plants are pruned with a reduced height. The crop cycle slows down and, therefore, reduces the risk of pest and disease attacks. In addition, the high planting density results in high yields, and the fruits, being from the first bunch, will have a large size and uniform quality. However, the cost of hybrid tomato seeds may burden the production system with only one bunch.

The production of tomatoes with two bunches is an advantageous alternative in high planting densities, due to their higher yield, if compared to those with only one bunch, and, under these conditions, the fruits continue to have commercially desirable size and quality, and the higher production allows a better amortization of the seed cost of hybrid varieties. It is also worth noting that the cultivation cycle remains short, what is desirable for the management of pests and diseases carried out preventively between successive crops, in hydroponics.

This study aimed to evaluate the yield and fruit quality of hybrid tomato (Rebeca) cultivated in a hydroponic sub-irrigation system, with different planting densities and number of bunches per plant.

\section{MATERIAL AND METHODS}

The experiment was carried out in a greenhouse of the Universidade Federal de Viçosa, Minas Gerais state, Brazil, between 04 May 2006 and 27 October 2006. The hybrid tomato Rebeca (long life and indeterminate growth type) was cultivated in a subirrigation hydroponic system, using expanded clay as substrate.

The seeds were germinated in plastic trays containing phenolic foam plates with $5 \mathrm{~cm} \mathrm{x} 5 \mathrm{~cm} \mathrm{x}$ $3.8 \mathrm{~cm}$ cells. From the $1 \mathrm{st}$ to the 14 th day after sowing, the seedlings were irrigated with tap water. From the 14th day, the plants were irrigated with a nutrient solution with $50 \%$ ionic strength (Fernandes et al. 2002) (Table 1). All irrigations were carried out once a day, after 6 p.m., in a volume sufficient to saturate the substrate.

When the plants reached the stage of 4 to 6 definitive leaves, they were transplanted to the hydroponic system. The experimental plots were composed of asbestos cement cores $(3.75 \mathrm{~m}$ long by $0.85 \mathrm{~m}$ wide at the top, $0.60 \mathrm{~m}$ wide at the base and $0.20 \mathrm{~m}$ high) closed at the ends, waterproofed and filled with expanded clay with 8-13 $\mathrm{mm}$ in diameter, to a height of $0.17 \mathrm{~m}$ from the base. Each plot was divided in half, and in each half a subplot was applied.

The experimental design was a randomized complete block, with three replications. The plot 
consisted of planting densities of 11.1 plants $\mathrm{m}^{-2}$, 8.3 plants $\mathrm{m}^{-2}, 6.6$ plants $\mathrm{m}^{-2}$ and 5.5 plants $\mathrm{m}^{-2}$, obtained using the spacings of $30 \mathrm{~cm} \times 30 \mathrm{~cm}$, $30 \mathrm{~cm} \times 40 \mathrm{~cm}, 30 \mathrm{~cm} \times 50 \mathrm{~cm}$ and $30 \mathrm{~cm} \times 60 \mathrm{~cm}$. The subplots included the number of bunches, ie., plants with one or two bunches. The two central plants of each subplot were considered as a useful plot.

After transplanting, the temperature and relative air humidity inside the greenhouse were measured daily, using two thermometers and two hygrometers, placed at two different points at a height of $1.10 \mathrm{~m}$ from the floor surface. The plants were grown in a vegetative growth solution at full ionic strength. With the appearance of bunches, the nutrient solution was changed, and a fruiting solution, adapted from Fernandes et al. (2002), was applied (Table 1). The solution used in the vegetative growth phase contained: $\mathrm{N}=8 \mathrm{mmol} \mathrm{L}^{-1} ; \mathrm{P}=2 \mathrm{mmol} \mathrm{L}^{-1} ; \mathrm{K}=$ $4 \mathrm{mmol} \mathrm{L}-1 ; \mathrm{Ca}=2 \mathrm{mmol} \mathrm{L}^{-1} ; \mathrm{Mg}=1 \mathrm{mmol} \mathrm{L}^{-1} ; \mathrm{S}=$ $1 \mathrm{mmol} \mathrm{L}-1 ; \mathrm{Fe}=35 \mathrm{mmol} \mathrm{L}^{-1} ; \mathrm{Mn}=19 \mathrm{mmol} \mathrm{L}^{-1} ; \mathrm{B}=$ $21 \mathrm{mmol} \mathrm{L}^{-1} ; \mathrm{Zn}=4 \mathrm{mmol} \mathrm{L}^{-1} ; \mathrm{Cu}=0.9 \mathrm{mmol} \mathrm{L}^{-1}$; and $\mathrm{Mo}=0.7 \mathrm{mmol} \mathrm{L}^{-1}$. The solution used in the fruiting phase contained: $\mathrm{N}=12 \mathrm{mmol} \mathrm{L}^{-1} ; \mathrm{P}=$ $3 \mathrm{mmol} \mathrm{L}-\mathrm{K}=8.6 \mathrm{mmol} \mathrm{L}^{-1} ; \mathrm{Ca}=3 \mathrm{mmol} \mathrm{L}^{-1} ; \mathrm{Mg}=$ $1.5 \mathrm{mmol} \mathrm{L}^{-1} ; \mathrm{S}=1.5 \mathrm{mmol} \mathrm{L}^{-1} ; \mathrm{Fe}=59 \mathrm{mmol} \mathrm{L}^{-1}$; $\mathrm{Mn}=20 \mathrm{mmol} \mathrm{L}^{-1} ; \mathrm{B}=25 \mathrm{mmol} \mathrm{L}^{-1} ; \mathrm{Zn}=4 \mathrm{mmol} \mathrm{L}^{-1}$; $\mathrm{Cu}=1.3 \mathrm{mmol} \mathrm{L}^{-1}$; and $\mathrm{Mo}=0.7 \mathrm{mmol} \mathrm{L}^{-1}$.

The plants were tufted with a ribbon, and the apical pruning was performed when all the plants had three leaves above the first or the second bunch, according to the subplot, leaving only six fruits per bunch. The number of fruits per bunch

Table 1. Vegetative growth and fruiting nutritive solutions for tomato growing in a hydroponic system.

\begin{tabular}{lclc}
\hline \multicolumn{2}{c}{$\begin{array}{c}\text { Vegetative growth } \\
\text { nutritive solution }\end{array}$} & \multicolumn{2}{c}{$\begin{array}{c}\text { Fruiting } \\
\text { nutritive solution }\end{array}$} \\
\hline \multicolumn{1}{c}{ Fertilizers } & g 1,000 L-1 & \multicolumn{1}{c}{ Fertilizers } & g 1,000 L-1 \\
\hline $\mathrm{KH}_{2} \mathrm{PO}_{4}$ & 271.9 & $\mathrm{KH}_{2} \mathrm{PO}_{4}$ & 408.7 \\
$\mathrm{MgSO}_{4}$ & 247.4 & $\mathrm{MgSO}_{4}$ & 369.6 \\
$\mathrm{Ca}\left(\mathrm{NO}_{3}\right)_{2}$ & 400.0 & $\mathrm{Ca}\left(\mathrm{NO}_{3}\right)_{2}$ & 631.6 \\
$\mathrm{KNO}_{3}$ & 213.6 & $\mathrm{KNO}_{3}$ & 597.0 \\
$\mathrm{NaNO}_{3}$ & 151.4 & $\mathrm{FeCl}_{3}$ & 15.9 \\
$\mathrm{EDTA}_{3}-F e r r i c$ & 20.5 & $\mathrm{EDTA}-F e r r i c_{4}$ & 20.0 \\
$\mathrm{NH}_{4} \mathrm{Mo}_{7} \mathrm{O}_{24}$ & 0.2 & $\mathrm{NH}_{4} \mathrm{Mo}_{7} \mathrm{O}_{24}$ & 0.2 \\
$\mathrm{MnSO}_{4}$ & 3.7 & $\mathrm{MnSO}_{4}$ & 3.4 \\
$\mathrm{H}_{3} \mathrm{BO}_{3}$ & 1.3 & $\mathrm{H}_{3} \mathrm{BO}_{3}$ & 1.6 \\
$\mathrm{ZnSO}_{4}$ & 1.3 & $\mathrm{ZnSO}_{4}$ & 1.3 \\
$\mathrm{CuSO}_{4}$ & 0.1 & $\mathrm{CuSO}_{4}$ & 0.2 \\
\hline
\end{tabular}

Source: Adapted from Fernandes et al. (2002). was standardized to ensure the uniformity of size, maturation and fruit quality. During the conduction of the experiment, it was necessary to accomplish periodic thins to maintain the number of fruits and side shoots.

The volume of the nutrient solution loosed by evapotranspiration was completed with tap water on a daily basis, until it reached the initial volume of $167 \mathrm{~L}$ per experimental plot. The $\mathrm{pH}$ of the nutrient solution was daily monitored and adjusted to the range of 5.5 to 6.5 , using $\mathrm{HCl}$ or $\mathrm{NaOH}$. The solutions were periodically replaced, based on the reduction of the electrical conductivity, allowing up to $30 \%$ of depletion. The nutrient solution was delivered to the plants for 15 min every hour in the daytime by the automatic activation of a motor pump. Watering started at 6 a.m. and finished at 6 p.m. During the night, only two waterings of $15 \mathrm{~min}$ each were made, one at 11 p.m. and one at 2 a.m.

Harvest started at 103 days after transplanting (DAT) and ended at 134 DAT. The fruits were classified according to Brasil (1995) (Table 2). The fresh matter weight, fruit diameter and pericarp thickness were evaluated in six fruits harvested per bunch. Soluble solids ( ${ }^{\circ}$ Brix), citric acid (\%), total carotenoids $\left(\mu \mathrm{g} \mathrm{g}^{-1}\right)$, lycopene $\left(\mu \mathrm{g} \mathrm{g}^{-1}\right)$ and $\mathrm{pH}$ were evaluated in two fruits of the bunch showing $100 \%$ of red surface.

In the last harvest, the plant height, insertion height of the first bunch and stem diameter (measured in the region just above the first bunch and below the first leaf in the position above it) were determined. In addition, the dry matter percentage of leaflets and petioles were evaluated.

For the leaf chemical analysis, the index leaf was harvested immediately below the bunch, at the time of harvesting the first ripe fruit, and, for the fruit chemical analysis, two fruits were collected per repetition. The sampled material was washed in deionized water and oven dried with forced air circulation at $70{ }^{\circ} \mathrm{C}$, until constant weight. The plant

Table 2. Size classes used in the classification of tomato fruits.

\begin{tabular}{ll}
\hline \multicolumn{1}{c}{ Class $^{1}$} & LTD $(\mathrm{mm})^{2}$ \\
\hline Giant & $>100$ \\
Big & $>80$ up to 100 \\
Medium & $>65$ upt to 80 \\
Small & $>50$ up to 65 \\
\hline
\end{tabular}

${ }^{1}$ Brasil 1995. ${ }^{2}$ LTD: larger transverse diameter. 
material was then milled in a Wiley mill equipped with a 20 mesh screen. Total-N was determined by the Kjeldahl method (Bremner 1965). The nutrients $P$, $\mathrm{K}, \mathrm{Ca}, \mathrm{Mg}, \mathrm{S}, \mathrm{Fe}, \mathrm{Mn}, \mathrm{Zn}$ and $\mathrm{Cu}$ were analysed after mineralization, by nitric-perchloric digestion. $\mathrm{P}$ was dosed colorimetrically by the reduction method of phosphomolybdate by vitamin C (Braga \& Defelipo 1974); K quantified by flame emission photometer; $\mathrm{Ca}, \mathrm{Mg}, \mathrm{Fe}, \mathrm{Mn}, \mathrm{Zn}$ and $\mathrm{Cu}$ quantified by atomic absorption spectrophotometry; and S quantified by sulfate turbidimetry (Blanchar et al. 1965). B was determined colorimetrically by the Azomethine $\mathrm{H}$ method (Wolf 1974), after the dry mineralization in kiln at $550{ }^{\circ} \mathrm{C}$. For the quantification of $\mathrm{P}, \mathrm{S}$ and $\mathrm{B}$, a molecular absorption spectrophotometer was used.

All obtained data were submitted to analysis of variance and qualitative effects of the treatments were compared by the Tukey test at $5 \%$ of probability. Quantitative data were submitted to regression analysis.

\section{RESULTS AND DISCUSSION}

The increase in the number of bunches had a positive effect on yield per plant (Table 3 ). Cultivated plants with two bunches were more productive than plants with only one bunch at all planting densities, but the yield per plant was not influenced by planting density for the same number of bunches.

There was no difference in production per plant, regardless of planting density, either in plants with one (Figure 1A) or two (Figure 1B) bunches.

The total production per area was influenced by the interaction planting density $\mathrm{x}$ number of bunches per plant, increasing with the increase of planting densities and number of bunches per plant. The management of planting density interferes with the balance between the vegetative and reproductive growth of the tomato plant, since it changes the amount of solar radiation reaching the interior of the vegetative canopy and, consequently, affects

Table 3. Characteristics of plants and fruits of Rebeca hybrid tomato cultivated in hydroponics, according to planting densities and number of bunches per plant.

\begin{tabular}{|c|c|c|c|c|c|c|}
\hline \multirow{2}{*}{$\mathrm{N}^{\mathrm{o}}$ of bunches } & \multicolumn{4}{|c|}{ Plant $\mathrm{m}^{-2}$} & \multirow{2}{*}{ Average } & \multirow{2}{*}{ CV $(\%)$} \\
\hline & 11.1 & 8.3 & 6.6 & 5.5 & & \\
\hline \multicolumn{7}{|c|}{ Production per plant (g) } \\
\hline 1 & $1,088 b^{*}$ & $1,124 \mathrm{~b}$ & $1,004 \mathrm{~b}$ & $1,102 \mathrm{~b}$ & 1,080 & \multirow{2}{*}{7.04} \\
\hline 2 & $2,105 \mathrm{a}$ & $1,906 \mathrm{a}$ & $2,086 \mathrm{a}$ & $2,322 \mathrm{a}$ & 2,105 & \\
\hline \multicolumn{7}{|c|}{ Fruit weight $(\mathrm{g})$} \\
\hline 1 & $179.03^{\mathrm{ns}}$ & $193.01^{\mathrm{ns}}$ & $179.58^{\mathrm{ns}}$ & $183.61^{\mathrm{ns}}$ & 183.81 & \multirow{2}{*}{7.57} \\
\hline 2 & 175.42 & 175.45 & 185.01 & 198.02 & 183.48 & \\
\hline \multicolumn{7}{|c|}{ Fruit diameter $(\mathrm{mm})$} \\
\hline 1 & $72.17^{\mathrm{ns}}$ & $74.10^{\mathrm{ns}}$ & $72.08^{\mathrm{ns}}$ & $72.79^{\text {ns }}$ & 72.79 & \multirow{2}{*}{2.46} \\
\hline 2 & 72.08 & 70.86 & 72.64 & 75.44 & 72.76 & \\
\hline \multicolumn{7}{|c|}{ Mesocarp thickness (mm) } \\
\hline 1 & $9.67^{\mathrm{ns}}$ & $9.44^{\mathrm{ns}}$ & $9.49^{\mathrm{ns}}$ & $9.91^{\mathrm{ns}}$ & 9.63 & \multirow{2}{*}{3.61} \\
\hline 2 & 9.65 & 9.55 & 9.67 & 9.73 & 9.65 & \\
\hline \multicolumn{7}{|c|}{ Fruit soluble solids ( ${ }^{\circ}$ Brix) } \\
\hline 1 & $3.97^{\mathrm{ns}}$ & $4.03^{\mathrm{ns}}$ & $3.73^{\mathrm{ns}}$ & $4.47^{\mathrm{ns}}$ & 4.05 & \multirow{2}{*}{6.95} \\
\hline 2 & 3.87 & 3.90 & 4.20 & 4.07 & 4.01 & \\
\hline \multicolumn{7}{|c|}{ Fruit citric acid (\%) } \\
\hline 1 & $0.22^{\mathrm{ns}}$ & $0.22^{\mathrm{ns}}$ & $0.21^{\mathrm{ns}}$ & $0.22^{\text {ns }}$ & 0.22 & \multirow[b]{2}{*}{6.26} \\
\hline 2 & 0.24 & 0.24 & 0.23 & 0.23 & 0.24 & \\
\hline \multicolumn{7}{|c|}{ Total carotenoids $\left(\mu \mathrm{g} \mathrm{g}^{-1}\right)$} \\
\hline 1 & $127.84^{\mathrm{ns}}$ & $128.48^{\mathrm{ns}}$ & $129.26^{\mathrm{ns}}$ & $129.65^{\mathrm{ns}}$ & 128.81 & \multirow{2}{*}{1.28} \\
\hline 2 & 128.87 & 127.95 & 128.38 & 128.11 & 128.33 & \\
\hline \multicolumn{7}{|c|}{ Lycopene $\left(\mu \mathrm{g} \mathrm{g}^{-1}\right)$} \\
\hline 1 & $86.87^{\mathrm{ns}}$ & $89.63^{\text {ns }}$ & $89.70^{\mathrm{ns}}$ & $90.30^{\mathrm{ns}}$ & 89.13 & \multirow{2}{*}{2.64} \\
\hline 2 & 89.43 & 89.33 & 88.30 & 87.83 & 88.72 & \\
\hline \multicolumn{7}{|c|}{ Fruit $\mathrm{pH}$} \\
\hline 1 & $4.13^{\mathrm{ns}}$ & $4.17^{\mathrm{ns}}$ & $4.07^{\mathrm{ns}}$ & $4.08^{\mathrm{ns}}$ & 4.11 & \multirow{2}{*}{2.68} \\
\hline 2 & 4.09 & 4.11 & 4.09 & 4.12 & 4.10 & \\
\hline
\end{tabular}

\footnotetext{
* Averages followed by the same lowercase letter in the column do not differ from each other at $5 \%$ of probability by the Tukey test.
} 

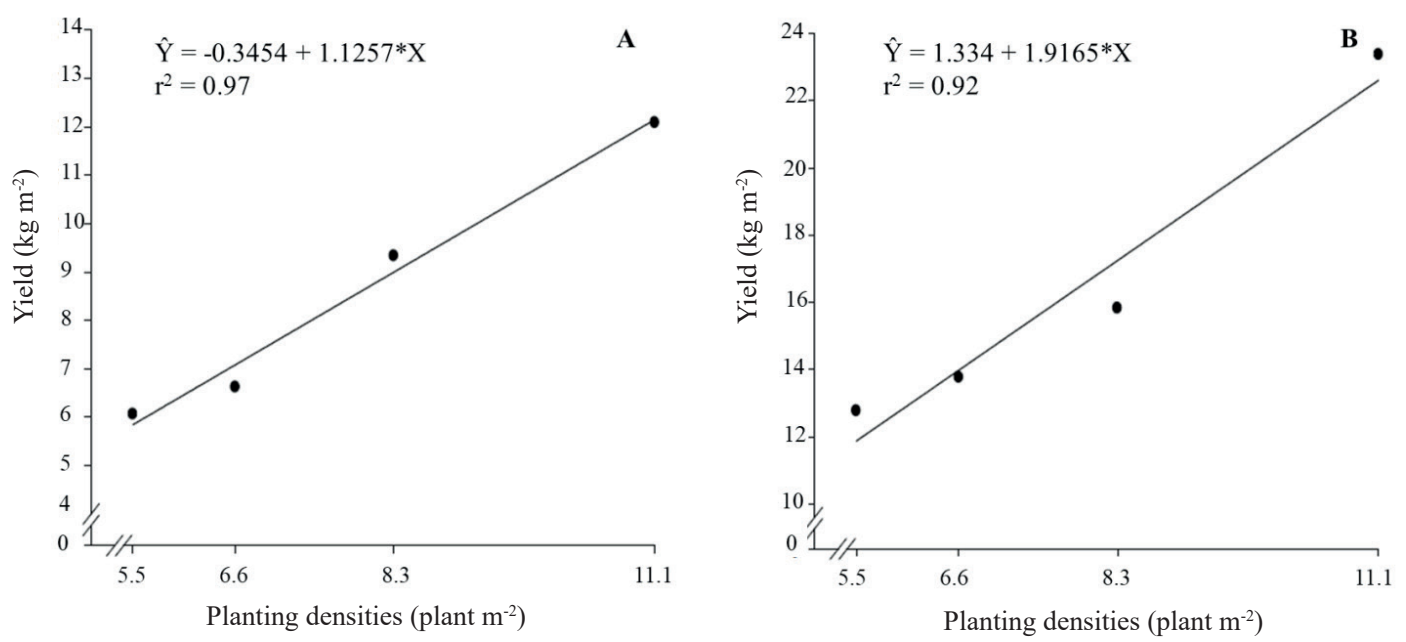

Figure 1. Tomato yield as a function of planting densities, with plants led with one (A) and two (B) bunches.

the photosynthetic rate. Changes in the strength of the sources, through a change in planting density or increased radiation availability, indirectly affect the distribution of dry matter between plant organs (Duarte \& Peil 2010).

Tomato plants conducted with a single bunch, in a greenhouse, with a Nutrient Film Technique system, at a high density $(20 \mathrm{~cm} \times 20 \mathrm{~cm})$, showed a higher yield (Santos et al. 2013). Similar results were found in other studies with tomato cultivated in soil and with different spacings between plants. It was observed that the higher the planting density the greater the yield (Camargos et al. 2000, Seleguini et al. 2006, Hachmann et al. 2014).

Some authors affirm that, although there is an increase in the tomato production with plant densities, the average fruit mass decreases (Streck et al. 1998, Camargos et al. 2000, Logendra et al. 2001). In this experiment, the average fruit mass was not influenced by planting density and number of bunches per plant. It is known that the fruits of the first bunch are larger, if compared to the fruits of the other bunches, and, as the plant produces upper bunches, the fruits will decrease in size. One of the causes for this behaviour is the competition of the fruits, in the different positions, by water, nutrients and photoassimilates. In this study, as the plants were produced with only one or two bunches, there was no marked competition between the fruits. Hydroponic cultivation has contributed to reduce the competition, given the good availability of water and nutrients throughout the crop cycle.

In this assay, the plants produced fruits with $183.64 \mathrm{~g}$ of average weight, $72.7 \mathrm{~mm}$ in diameter and
$9.6 \mathrm{~mm}$ of mesocarp thickness (Table 3). According to the classification by Brasil 1995 (Table 2), $100 \%$ of average fruits were produced.

Fruit quality (soluble solids, citric acid, carotenoids, lycopene and $\mathrm{pH}$ ) was not influenced by density or number of bunches per plant (Table 3 ). The total soluble solids ( $\left.{ }^{\circ} \mathrm{Brix}\right)$ content is an important quality attribute during the ripening stage for many fresh fruits, including tomato (Siddiqui et al. 2015), and, for the in natura market, high-quality tomato fruits must have percentages of ${ }^{\circ} \mathrm{Brix}$ above three (Schwarz et al. 2013). In this study, it was observed that the values for total soluble solids were higher than the value suggested above.

The amount of sugars stored in tomato fruits is the main constituent of post-harvest quality, being directly related to its flavour (Beckles 2012, Ramos et al. 2013). The flavour is the most important aspect for the consumer of fresh fruits, and a balanced proportion of sugar/acid is essential. High levels of sugars and acids are required for a better fruit palate/ flavour. High acid and low sugar contents can result in an astringent/sour taste. Contrarily, low acid and high sugar contents result in a softer flavour and, although it is very sweet, it is considered tasteless. Even when with low levels of acids and sugars, the result is a tasteless fruit (Morgan 2004).

The acidity in tomato fruits indicates the amount of acids present, and the astringency of the fruit is the main influence on its flavour (Nascimento et al. 2013). In tomato for in natura consumption, citric acid values were $0.36 \%(0.36 \mathrm{~g}$ of citric acid in $100 \mathrm{~g}$ of fruit) (Silva et al. 2013), while, in fresh 
'Manyla' tomato juice, citric acid levels varied from $0.29 \%$ to $0.33 \%$ (Gatta et al. 2015). In this study, the values obtained (between $0.21 \%$ and $0.24 \%$ of citric acid) were relatively low, indicating fruits with low acidity.

The tomato fruit is considered a source of carotenoids, especially lycopene and $\beta$-carotene (Alvarenga \& Coelho 2013). The first one is found in a greater quantity and acts as an important antioxidant, while the second is found in a lower amount in the fruit, showing a provitamin A activity (Demiray et al. 2013, Mladenovic et al. 2014). Carotenoids are pigments synthesized during fruit ripening, with $\beta$-carotene reaching the maximum concentration before the end of maturation, while lycopene continues to be accumulated (Perveen et al. 2015).

The carotenoid contents found in the fruits of this hybrid did not present differences, when the number of bunches and the planting density varied. As noted above, the concentration of these compounds increases during tomato maturation, with air temperature being an important factor related to the accumulation of lycopene and $\beta$-carotene in tomato fruits. Temperatures of 22$25{ }^{\circ} \mathrm{C}$ are considered ideal for the biosynthesis of this carotenoid. Below $10{ }^{\circ} \mathrm{C}$ and above $30{ }^{\circ} \mathrm{C}$, the biosynthesis becomes compromised (Dorais et al. 2010). During the experiment under discussion, the weekly average of minimum air temperature varied between $6.0^{\circ} \mathrm{C}$ and $17{ }^{\circ} \mathrm{C}$, being the maximum between $26.9^{\circ} \mathrm{C}$ and $39.4{ }^{\circ} \mathrm{C}$. It is worth to note that the hybrid Rebeca maintained the biosynthesis of total carotenoids, even with diurnal air temperatures above $30{ }^{\circ} \mathrm{C}$. Their carotenoids contents remained between $128 \mu \mathrm{g} \mathrm{g}^{-1}$ and $130 \mu \mathrm{g} \mathrm{g}^{-1}$, i.e., within the adequate ranges mentioned in the literature. It is possible that the maximum temperature found did not occur long enough to compromise the biosynthesis of carotenoids in the studied hybrid.

As for $\mathrm{pH}$, foods are classified into three groups: low acidity ( $\mathrm{pH}$ above 4.5$)$; acid ( $\mathrm{pH}$ between 4.0 and 4.5) and very acid ( $\mathrm{pH}$ lower than 4.0) (Gava et al. 2009). Tomato fruits usually have a $\mathrm{pH}$ below 4.6, and, this way, they are considered acidic foods (Anthon \& Barrett 2012). Although the citric acid concentration indicated fruits with a low acidity, in the present study, the fruits presented $\mathrm{pH}$ values below 4.6, agreeing with the results for tomato fruits found in the literature (Figàs et al. 2015, Gatta et al. 2015, Peixoto et al. 2018).

There was no significant effect of planting densities and number of bunches on the proportion of dry matter allocated in leaflets and petioles and insertion height of the first bunch. There was difference only for plant height, when comparing plants with one and two bunches (Table 4).

The plant height was obviously higher when two bunches were left, but the planting density did not influence the plant height, i.e., the plants did not tend to the exaggerated growth of the stem in search of luminosity with increasing planting densities. This result disagrees with those found by Camargos et al. (2000) and Seleguini et al. (2006), in protected tomato cultivation, indicating that, under hydroponic cultivation, with only one and two bunches, the competition for water, light and nutrients was

Table 4. Characteristics of the Rebeca hybrid tomato plant cultivated in hydroponics, according to planting densities and number of bunches per plant.

\begin{tabular}{|c|c|c|c|c|c|c|}
\hline \multirow{2}{*}{$\mathrm{N}^{\mathrm{o}}$ of bunches } & \multicolumn{4}{|c|}{ Plant $\mathrm{m}^{-2}$} & \multirow{2}{*}{ Average } & \multirow{2}{*}{ CV (\%) } \\
\hline & 11.1 & 8.3 & 6.6 & 5.5 & & \\
\hline \multicolumn{7}{|c|}{ Leaf dry matter production (\%) } \\
\hline 1 & $10.23^{\mathrm{ns}}$ & $8.38^{\mathrm{ns}}$ & $8.41^{\mathrm{ns}}$ & $9.46^{\mathrm{ns}}$ & 9.12 & 6.78 \\
\hline 2 & 9.29 & 9.01 & 8.83 & 9.96 & 9.27 & \\
\hline \multicolumn{7}{|c|}{ Petiole dry matter production (\%) } \\
\hline 1 & $12.44^{\mathrm{ns}}$ & $9.89^{\text {ns }}$ & $10.26^{\mathrm{ns}}$ & $11.08^{\mathrm{ns}}$ & 10.92 & 11.23 \\
\hline 2 & 11.01 & 9.59 & 11.44 & 11.87 & 10.98 & \\
\hline \multicolumn{7}{|c|}{ Plant height $(\mathrm{cm})$} \\
\hline 1 & $126.33 \mathrm{~b}^{*}$ & $121.67 \mathrm{~b}$ & $101.33 \mathrm{~b}$ & $104.33 \mathrm{~b}$ & 113.42 & 11.07 \\
\hline 2 & $139.67 \mathrm{a}$ & $128.17 \mathrm{a}$ & $142.33 \mathrm{a}$ & $137.67 \mathrm{a}$ & 136.96 & \\
\hline \multicolumn{7}{|c|}{ Insertion height of the first bunch (cm) } \\
\hline 1 & $96.33^{\mathrm{ns}}$ & $83.67^{\mathrm{ns}}$ & $75.33^{\mathrm{ns}}$ & $77.83^{\text {ns }}$ & 83.29 & 10.03 \\
\hline 2 & 81.67 & 75.50 & 77.50 & 85.50 & 80.04 & \\
\hline
\end{tabular}

* Averages followed by the same letter in the column do not differ from each other at $5 \%$ of probability by the Tukey test. 
minimal. From the aforementioned authors, the first group cultivated the Carmen hybrid, varying the spacing between plants in the row $(30 \mathrm{~cm}$ and 60 $\mathrm{cm})$ and the number of bunches per plant (3, 5 and 7), maintaining $1.0 \mathrm{~m}$ between rows. Similarly, the second group cultivated the hybrid Lasting and varied the spacing between plants in the row $(30 \mathrm{~cm}, 40 \mathrm{~cm}$, $50 \mathrm{~cm}$ and $60 \mathrm{~cm}$ ) and number of bunches per plant (3, 4 and 5), maintaining $1.0 \mathrm{~m}$ between rows. For both studies, there was an increase in plant height for the smallest spacing. The plant height may vary due to several factors, such as crop growing, planting season, number of branches left per plant (Oliveira et al. 1995) and material used to cover the protected environment (Papadopoulos \& Hão 1997).

Concerning the macro and micronutrient contents in leaves and fruits, significant differences were observed among the treatments for total-N, B and $\mathrm{Zn}$, respectively.

The total-N content in tomato leaves varied significantly for different planting densities. The total-N content in the leaf increased with increasing planting densities from 5.5 plants $\mathrm{m}^{-2}$ to 6.6 plants $\mathrm{m}^{-2}$, with a subsequent drop (Figure 2A). The total-N leaf content ranged from $27.4 \mathrm{~g} \mathrm{~kg}^{-1}$ to $33.2 \mathrm{~g} \mathrm{~kg}^{-1}$, remaining close to the range of concentrations considered adequate: from $28.0 \mathrm{~g} \mathrm{~kg}^{-1}$ to $60.0 \mathrm{~g} \mathrm{~kg}^{-1}$ (Jones Junior 1999, Camargos et al. 2000, Fernandes et al. 2002).

For the highest planting density (11.1 plants $\left.\mathrm{m}^{-2}\right)$, the total-N content in the leaves was below the minimum considered adequate by Jones Junior (1999): $28.0 \mathrm{~g} \mathrm{~kg}^{-1}$. This may be justified by the likely competition between plants by N. Thus, it is suggested that, in future studies using the same nutrient solutions of the present research, it is necessary to increase the $\mathrm{N}$ concentration for densities of more than 9 plants $\mathrm{m}^{-2}$.

Regarding the total-N content in the fruits, a significant difference was observed only for planting densities. The total-N and $\mathrm{P}$ contents in the fruits presented a linear behaviour, decreasing with the increase of the planting density (Figures 2B and 3A, respectively). Although Mueller \& Wamser (2009) observed that the production of tomato plants is positively correlated with an increased planting density and negatively with fruit size, this is mainly due to the scarcity of photoassimilates for each fruit, what was not observed in this research. In this case, the dilution effect of these nutrients on a higher fruit production probably caused the reductions of these concentrations, without, however, reducing the production to a limiting level. The concentrations obtained in the fruits for total-N remained within the range of reference values found in the literature (Fernandes et al. 2002). For P, the range of contents obtained in fruits by Fernandes et al. (2007) was 2.2$3.0 \mathrm{~g} \mathrm{~kg}^{-1}$, lower than the range found in the present study (3.2-4.1 $\left.\mathrm{g} \mathrm{kg}^{-1}\right)$.

The leaf content of B, contrary to what would be expected, increased from the lowest to the highest planting density (Figure 3B). This fact is probably because nutrient replacements are based on the reduction of the electrical conductivity, which evaluates the depletion in the concentration of ions as a whole, without considering the nutrients
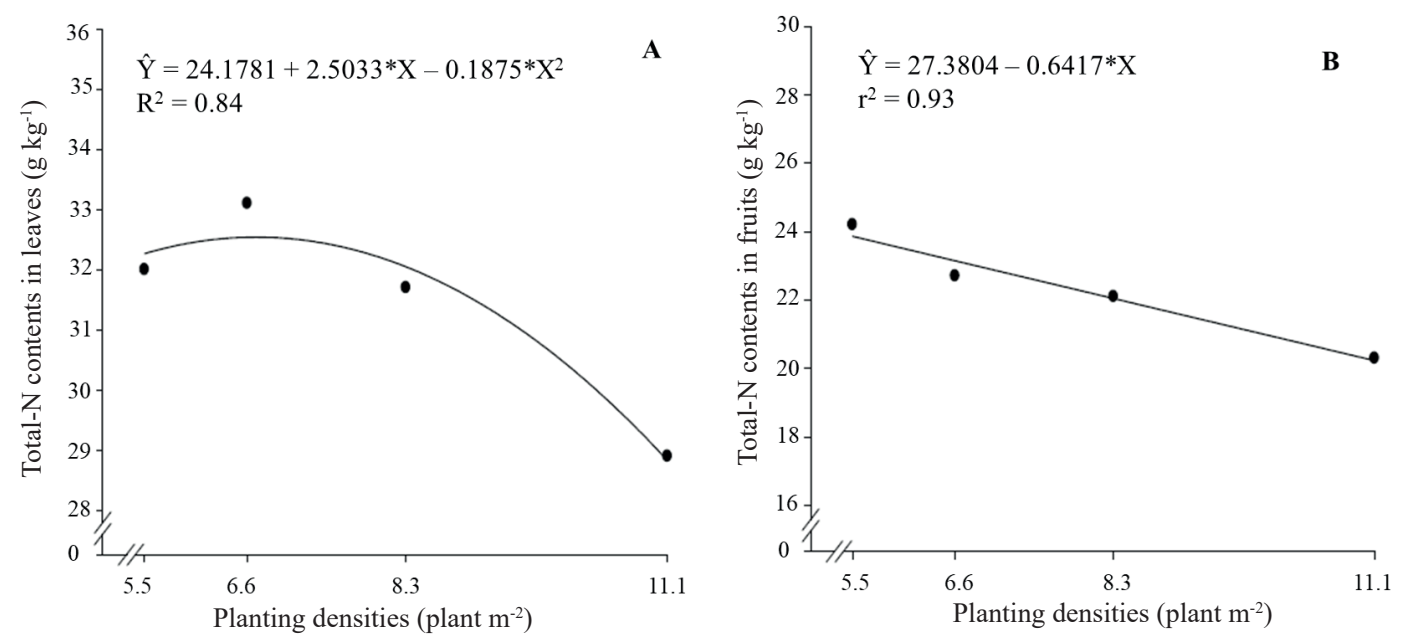

Figure 2. Total nitrogen contents in leaves (A) and fruits (B) of Rebeca tomato hybrid, as a function of planting densities. 
individually. Greater numbers of replenishments were made in the plots with higher plant density, so it is possible that these plots have accumulated more B not absorbed by the plants over time. The concentration range observed was $82.1-110.4 \mathrm{mg} \mathrm{kg}^{-1}$ of B, slightly above the values reported by Jones Junior (1999), which states that they should be between $25.0 \mathrm{mg} \mathrm{kg}^{-1}$ and $100.0 \mathrm{mg} \mathrm{kg}^{-1}$. As the contents of B in the leaves were very close to the maximum value considered adequate, and the limit between lack and toxicity for this micronutrient can be narrow, it is proposed to reduce the $\mathrm{B}$ concentration of the nutrient solution in future studies.

A significant difference was observed for $\mathrm{Zn}$ content in leaves and fruits, between treatments of planting density, whose behaviour was linear, increasing with the decrease of planting density (Figures 4A and 4B, respectively). Such behaviour is probably due to the increase in demand, when more plants were grown in the same experimental plot. However, leaf concentrations were relatively high, ranging from $72.6 \mathrm{mg} \mathrm{kg}^{-1}$ to $121.2 \mathrm{mg} \mathrm{kg}^{-1}$, although they agreed with the adequate range reported in the literature, i.e., between $20.0 \mathrm{mg} \mathrm{kg}^{-1}$ and $100.0 \mathrm{mg} \mathrm{kg}^{-1}$ (Jones Junior 1999, Fernandes et al. 2007). It is possible that there is a contamination with $\mathrm{Zn}$ by the fertilizers used to compose the nutrient solution.

Even with leaf $\mathrm{Zn}$ contents above the ideal, at planting densities of 6.6 plants $\mathrm{m}^{-2}$ and 5.5 plants $\mathrm{m}^{-2}$, no symptoms of $\mathrm{Zn}$ toxicity were observed. It is suggested that, in future researches
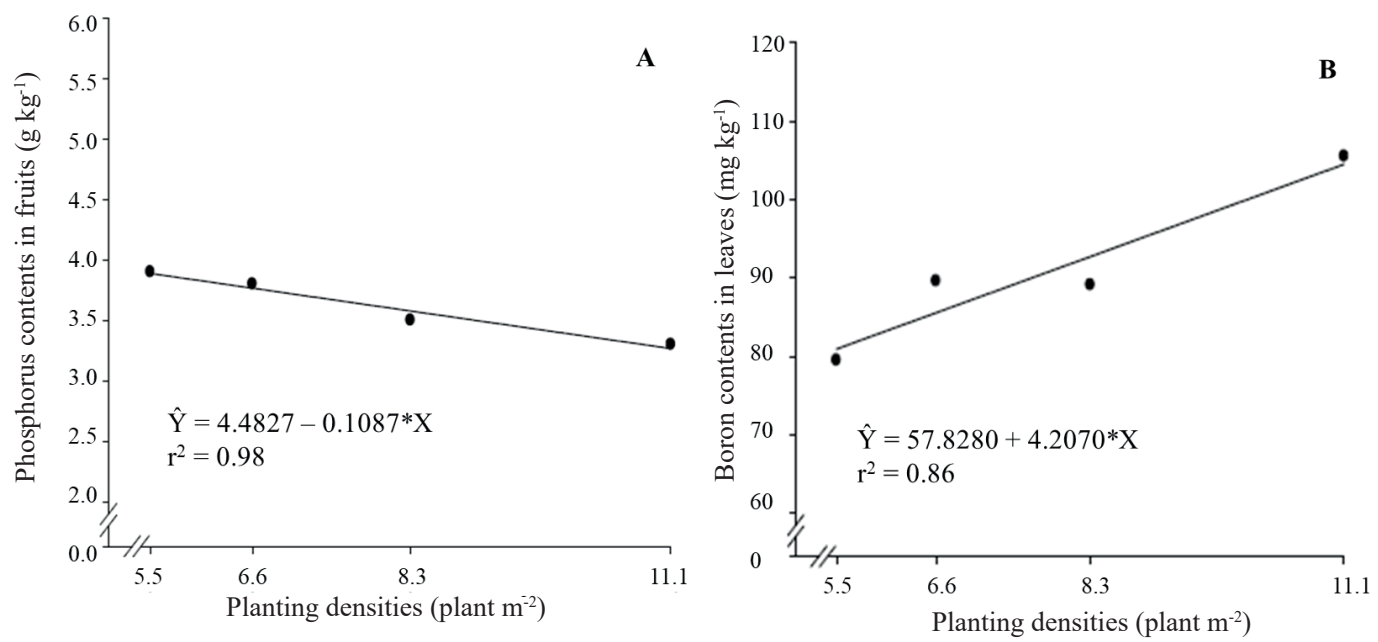

Figure 3. Phosphorus contents obtained in fruits (A) and boron obtained in leaves (B) of Rebeca hybrid tomato, as a function of planting densities.
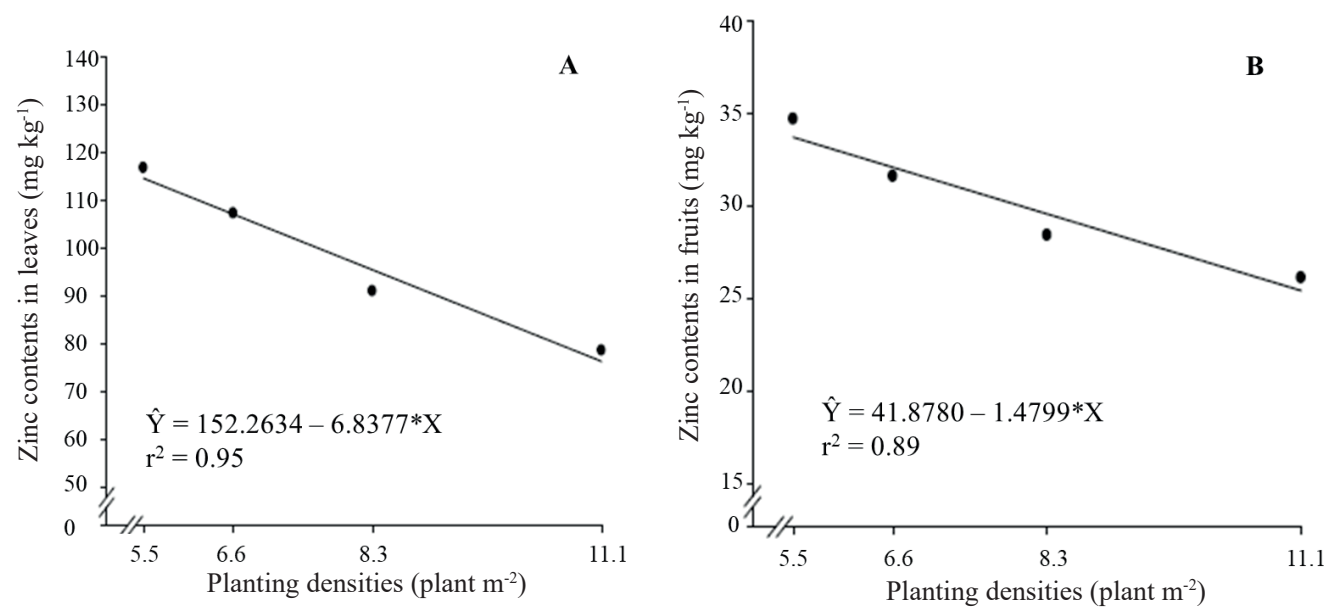

Figure 4. Zinc contents obtained in leaves (A) and fruits (B) of Rebeca hybrid tomato, as a function of planting densities. 
using these nutrient solutions, there is a reduction of $\mathrm{Zn}$ concentration to densities lower than 8 plants $\mathrm{m}^{-2}$.

Summarizing, the fruit quality was not influenced by the treatments and neither the total production, by the variations observed, in the nutrient contents of tomato leaves and fruits, but these features were affected by the interaction planting density $\mathrm{x}$ number of bunches. In view of this, it is suggested that, in future studies, using the same cultivation system presented here, planting densities higher than 11.1 plants $\mathrm{m}^{-2}$ be tested.

\section{CONCLUSIONS}

1. For the Rebeca hybrid tomato, in a hydroponic system, a planting density from 5.5 plants $\mathrm{m}^{-2}$ to 11.1 plants $\mathrm{m}^{-2}$ and two single bunches increased yield from $5.84 \mathrm{~kg} \mathrm{~m}^{-2}$ to $22.61 \mathrm{~kg} \mathrm{~m}^{-2}$, over a cycle of 134 days, without altering its marketable quality;

2. The observed variations for mineral nutrient content in the leaves and fruits of Rebeca hybrid tomato cultivated with one or two bunches, at densities of 5.5 plants $\mathrm{m}^{-2}$ to 11.1 plants $\mathrm{m}^{-2}$, did not compromise the fruit quality and did not affect the production of marketable fruits.

\section{ACKNOWLEDGMENTS}

The authors thank the Conselho Nacional de Desenvolvimento Científico e Tecnológico (CNPq), for the financial support, and Coordenação de Aperfeiçoamento de Pessoal de Nível Superior (Capes), for granting a master's degree to the first author.

\section{REFERENCES}

ALVARENGA, M. A. R.; COELHO, F. S. Valor nutricional. In: ALVARENGA, M. A. R. (Ed.). Tomate: produção em campo, casa de vegetação e hidroponia. Lavras: Ed. Universitária de Lavras, 2013. p. 25-28.

ANDRIOLO, J. L. et al. Caracterização e avaliação de substratos para o cultivo do tomateiro fora do solo. Horticultura Brasileira, v. 17, n. 3, p. 215-219, 1999.

ANDRIOLO, J. L.; FALCÃO, L. L. Efeito da poda de folhas sobre a acumulação de matéria seca e sua repartição para os frutos do tomateiro cultivado em ambiente protegido. Revista Brasileira de Agrometereologia, v. 8, n. 1, p. 75-83, 2000.

ANTHON, G. E.; BARRETT, D. M. Pectin methylesterase activity and other factors affecting $\mathrm{pH}$ and titratable acidity in processing tomatoes. Food Chemistry, v. 132, n. 2, p. 915-920, 2012.

BECKLES, D. M. Factors affecting the postharvest soluble solids and sugar content of tomato (Solanum lycopersicum L.) fruit. Postharvest Biology and Technology, v. 63, n. 1, p. 129-140, 2012.

BLANCHAR, R. W.; REHM, G.; CALDWELL, A. C. Sulfur in plant material by digestion with nitric and perchloric acid. Proceedings of the Soil Science Society of America, v. 29, n. 1, p. 71-72, 1965.

BRAGA, J. M.; DEFELIPO, B. Determinação espectrofotométrica de fósforo em extratos de solos e plantas. Revista Ceres, v. 21, n. 113, p. 73-85, 1974.

BRASIL. Ministério da Agricultura, do Abastecimento e da Reforma Agrária. Portaria $\mathrm{n}^{\circ} 553$, de 30 de agosto de 1995. Regulamento Técnico MERCOSUL de identidade e qualidade do tomate. Diário Oficial da União. Brasília, DF, 19 set. 1995. Seção 1, p. 8.

BREMNER, J. M. Total nitrogen. In: BLACK, C. A. (Ed.). Methods of soil analysis. Madison: American Society of Agronomy, 1965. p. 1149-1178.

CAMARGOS, M. I.; FONTES, P. C. R.; CARDOSO, A. A. Produção de tomate longa vida em estufa, influenciada por espaçamento e número de racimos por planta. Horticultura Brasileira, v. 18, suppl., p. 563-564, 2000.

DEMIRAY, E.; TULEK, Y. E.; YILMAZ, Y. Degradation kinetics of lycopene, $\beta$-carotene and ascorbic acid in tomatoes during hot air drying. LWT: Food Science and Technology, v. 50, n. 1, p. 172-176, 2013.

DORAIS, M.; GOSSELIN, A.; PAPADOPOULOS, A. P. Greenhouse tomato fruit quality. In: JANICK, J. (Ed.). Horticultural Reviews. New York: John Wiley \& Sons, 2010. p. 239-319.

DUARTE, T. S.; PEIL, R. M. N. Relações fonte:dreno e crescimento vegetativo do meloeiro. Horticultura Brasileira, v. 28, n. 3, p. 271-276, 2010.

FERNANDES, A. A. et al. Cultivo sucessivo de plantas de tomate oriundas de sementes e propagação vegetativa em sistema hidropônico. Pesquisa Agropecuária Brasileira, v. 42, n. 7, p. 1013-1019, 2007.

FERNANDES, A. A.; MARTINEZ, H. E. P.; FONTES, P. C. R. Produtividade, qualidade dos frutos e estado nutricional do tomateiro tipo longa vida conduzido com um cacho, em cultivo hidropônico, em função das fontes de nutrientes. Horticultura Brasileira, v. 20, n. 4, p. 564-570, 2002.

FIGÀS, M. R. et al. Characterization of composition traits related to organoleptic and functional quality for the differentiation, selection and enhancement of local varieties of tomato from different cultivar groups. Food Chemistry, v. 187, n. 1, p. 517-524, 2015. 
GATTA, G. et al. Treated agro-industrial wastewater irrigation of tomato crop: effects on qualitative/quantitative characteristics of production and microbiological properties of the soil. Agricultural Water Management, v. 149, n. 1, p. 33-43, 2015.

GAVA, A. J.; SILVA, C. A. B.; FRIAS, J. R. G. Tecnologia de alimentos: princípios e aplicações. São Paulo: Nobel, 2009.

HACHMANN, T. L. et al. Cultivo do tomateiro sob diferentes espaçamentos entre plantas e diferentes níveis de desfolha das folhas basais. Bragantia, v. 73, n. 4, p. 399-406, 2014.

ILAHY, R. et al. Fractionate analysis of the phytochemical composition and antioxidant activities in advanced breeding lines of high-lycopene tomatoes. Food \& Function, v. 7, n. 1, p. 574-583, 2016.

JONES JUNIOR, J. B. Tomato plant culture: in the field, greenhouse, and home garden. Boca Raton: CRC Press, 1999.

LOGENDRA, L. S. et al. Greenhouse tomato limited cluster production systems: crop management practices affect yield. HortScience, v. 36, n. 5, p. 893-896. 2001.

MLADENOVIC, J. et al. The biologically active (bioactive) compounds in tomato (Lycopersicon esculentum Mill.) as a function of genotype. Bulgarian Journal of Agricultural Science, v. 20, n. 4, p. 877-882, 2014.

MORGAN, L. Tomato fruit flavor and quality evaluation. 2004. available at: <www.fertcut.com/search.cmf $>$. Access on: 25 Jul. 2018.

MUELLER, S.; WAMSER, A. F. Combinação da altura de desponte e do espaçamento entre plantas de tomate. Horticultura Brasileira, v. 27, n. 1, p. 64-69, 2009.

NASCIMENTO, A. R. et al. Qualidade de tomates de mesa cultivados em sistema orgânico e convencional no estado de Goiás. Horticultura Brasileira, v. 31, n. 4, p. 628-635, 2013.

NASIR, M. U. et al. Tomato processing, lycopene and health benefits: a review. Science Letters, v. 3, n. 1, p. 1-5, 2015.

OLIVEIRA, V. R. et al. Efeito do número de hastes por planta e poda apical na produção classificada de frutos de tomateiro (Lycopersicon esculentum Mill.). Ciência e Prática, v. 19, n. 4, p. 414-419, 1995.

PAPADOPOULOS, A. P.; HÃO, X. Effects of three greenhouse cover materials on tomato growth, productivity, and energy use. Scientia Horticulturae, v. 70, n. 2-3, p. 165-178, 1997.

PEIXOTO, et al. Post-harvest evaluation of tomato genotypes with dual purpose. Food Science and Technology, v. 38, n. 2, p. 255-262, 2018.
PEREIRA, C.; MARCHI, G.; SILVA, E. C. Produção de tomate-caqui em estufa. Lavras: Ed. UFLa, 1999.

PERVEEN, R. et al. Tomato (Solanum Lycopersicum) carotenoids and lycopenes chemistry: metabolism, absorption, nutrition, and allied health claims: a comprehensive review. Critical Reviews in Food Science and Nutrition, v. 55, n. 7, p. 919-929, 2015.

PURQUERIO, L. F. V.; TIVELLI, S. W. Manejo do ambiente em cultivo protegido. São Paulo: Codeagro, 2006.

RAMOS, A. R. P. et al. Qualidade de frutos de tomate 'Giuliana' tratados com produtos de efeitos fisiológicos. Semina: Ciências Agrárias, v. 34, n. 6, p. 3543-3552, 2013.

SANTOS, O. S. et al. Produção de tomates em hidroponia com diferentes espaçamentos. Pubvet, v. 7, n. 6, p. 420428, 2013.

SCHWARZ, K. et al. Desempenho agronômico e qualidade físico-química de híbridos de tomateiro em cultivo rasteiro. Horticultura Brasileira, v. 31, n. 3, p. 410-418, 2013.

SELEGUINI, A.; SENO, S.; JÚNIOR, M. J. A. F. Espaçamento entre plantas e número de racimos para tomateiro em ambiente protegido. Acta Scientiarum, v. 28, n. 3, p. 359-363, 2006.

SELEGUINI, A.; SENO, S.; ZIZAS, G. B. Influência do espaçamento entre plantas e número de cachos por planta na cultura do tomateiro, em condições de ambiente protegido. Horticultura Brasileira, v. 20, n. 2, p. 25-28, 2002.

SIDDIQUI, M. W.; AYALA-ZAVALA, J. F.; DHUA, R. S. Genotypic variation in tomatoes affecting processing and antioxidant properties. Critical Reviews in Food Science and Nutrition, v. 55, n. 13, p. 1819-1835, 2015.

SILVA, E. C.; ALVARENGA, P. P. M.; MACIEL, G. M. Avaliações físico-químicas de frutos de tomateiro em função de doses de potássio e nitrogênio. Bioscience Journal, v. 29, n. 6, p. 1788-1795, 2013.

SILVA, E. C.; MIRANDA, J. R. P.; ALVARENGA, M. A. R. Produção de tomate (L. esculentum Mill) cv. Carmem sob diferentes sistemas de desbrota e densidade de plantio. Horticultura Brasileira, v. 19, suppl., p. 288, 2001.

STRECK, N. A. et al. Influência da densidade de plantas e da poda apical drástica na produtividade do tomateiro em estufa de plástico. Pesquisa Agropecuária Brasileira, v. 33, n. 7, p. 1105-1112, 1998.

VINHA, A. F. et al. Organic versus conventional tomatoes: influence on physicochemical parameters, bioactive compounds and sensorial attributes. Food Chemical Toxicology, v. 67, n. 1, p. 139-144, 2014.

WOLF, B. Improvements in azomethine-H method for determination of boron. Communications in Soil Science and Plant Analysis, v. 5, n. 1, p. 39-44, 1974. 